Zeszyty Naukowe Szkoły Głównej Gospodarstwa Wiejskiego w Warszawie Problemy Rolnictwa Światowego tom 17 (XXXII), zeszyt 1, 2017: 53-62

DOI: 10.22630/PRS.2017.17.1.5

Marta Guth $^{1}$, Katarzyna Smędzik-Ambroży ${ }^{2}$

Uniwersytet Ekonomiczny w Poznaniu

\title{
Wpływ subsydiów wspólnej polityki rolnej na dochody gospodarstw mlecznych FADN w krajach Unii Europejskiej w latach 2004-2013
}

\section{The Impact of the Common Agricultural Policy Subsidies on the Income of FADN Dairy Farms in the European Union Countries in 2004-2013}

\begin{abstract}
Synopsis. Celem głównym artykułu była ocena wpływu subsydiów wspólnej polityki rolnej na dochody gospodarstw mlecznych FADN w latach 2004-2013. Zbadano udział subsydiów ogólem łącznie z dopłatami do inwestycji na poziom dochodu $\mathrm{z}$ gospodarstwa rolnego w przeliczeniu na jednostkę pracy rodziny (FWU) w gospodarstwach mlecznych FADN w krajach Unii Europejskiej z podziałem na kraje UE-10 i UE-15. Następnie zaprezentowano trendy kształtowania się dochodu z gospodarstwa rolnego/FWU z i bez dopłat w badanym okresie. W celu zaprezentowania, które z grup dopłat miały największy wpływ na kształtowanie się dochodu $\mathrm{z}$ gospodarstwa rolnego/FWU przeprowadzono regresję panelową. Na jej podstawie określono, że najbardziej istotne dla dochodów gospodarstw mlecznych FADN w latach 2005-2013 były dopłaty decoupled oraz dodatkowe wsparcie wraz z pozostałymi subsydiami.
\end{abstract}

Slowa kluczowe: WPR, dochody gospodarstw mlecznych, subsydia, regresja panelowa

\begin{abstract}
The main aim of the article was to assess the impact of the Common Agricultural Policy subsidies on the income of FADN dairy farms in 2004-2013. The share of total subsidies, including subsidies on investments on farm income per unit of work (FWU) on FADN dairy farms in EU countries, with the division to EU-12 and EU-15, was examined. The trend of family farm income with and without subsidies during the period under review was presented. In order to demonstrate which of the groups of subsidies had the greatest impact on family farm income, a panel regression was conducted. It turned out that the most significant for the FADN dairy farm income in 2005-2013 was decoupled payments and additional aid with other support.
\end{abstract}

Key words: CAP, revenues of milk farms, subsidies, panel regression

\section{Wprowadzenie}

Przyczyny zmian w otoczeniu podmiotów gospodarczych, wpływających na uzyskiwane przez nie wyniki produkcyjne, są coraz bardziej złożone i wynikają z przenikania i zmienności zjawisk demograficznych, ekonomicznych, społecznych, politycznych i prawnych (Runowski, 2011). W odniesieniu do gospodarstw rolnych kluczową rolę odgrywają również uwarunkowania przyrodnicze. Ich konsekwencją bowiem

${ }^{1}$ dr, Katedra Makroekonomii i Gospodarki Żywnościowej Uniwersytetu Ekonomicznego w Poznaniu. Al. Niepodległości 10, 61-875 Poznań, e-mail: marta.guth@ue.poznan.pl

${ }^{2}$ dr, Katedra Makroekonomii i Gospodarki Żywnościowej Uniwersytetu Ekonomicznego w Poznaniu.

Al. Niepodległości 10,61-875 Poznań, e-mail: katarzyna.smedzik-ambrozy@ue.poznan.pl 
mogą m.in. turbulencje rynku, wśród których można wymienić chociażby zmiany cen rynkowych, które ostatecznie wpływają na zmiany dochodów. Runowski (2011) zauważa, że „w podejściu klasycznym zmiany dochodów w rolnictwie thumaczy się wahaniami wydajności (plonów) roślin i wydajności zwierząt oraz wahaniami cen (Hergrens i in., 2001; Phimister i in., 2004). Niemniej niektórzy autorzy (Majewski i in., 2007), wśród czynników różnicujących dochody rolników w czasie wymieniają również oddziaływanie różnych instrumentów interwencji zewnętrznej (instrumenty polityki rolnej)”. Unijna polityka na rynku mleka, podobnie jak inne polityki sektorowe w ramach wspólnej polityki rolnej, została powołana do realizacji ogólnych celów WPR określonych w artykule 33 Traktatu ustanawiającego Wspólnotę Europejską (Dz.Urz. UE 2006 C 321E). Przepisy dotyczące wspólnej organizacji rynku mleka odnoszą się do czterech głównych celów:

- zapewnienia równowagi na rynku mleka poprzez dostosowywanie podaży do popytu na rynku mleka i przetworów mlecznych oraz ograniczanie nadwyżek strukturalnych.

- stabilizacji cen mleka i przetworów mlecznych,

- zapewnienia odpowiedniego poziomu życia ludności wiejskiej poprzez wzrost indywidualnych dochodów uzyskany dzięki zwiększeniu produktywności gospodarstw,

- poprawy konkurencyjności przetworów mlecznych na rynkach międzynarodowych poprzez dostosowanie cen europejskich do strukturalnie niższych cen na rynku światowym.

Należy jednakże zauważyć, że pomimo ewolucji WPR cel dotyczący zapewnienia odpowiedniego, stabilnego dochodu rolników jest wciąż aktualny [Czyżewski i Guth 2016]. Celem artykułu jest próba oceny wpływu subsydiów ze środków wspólnej polityki rolnej na poziom dochodu z gospodarstwa rolnego w przeliczeniu na jednostkę pracy własnej.

\section{Przegląd literatury}

W związku z faktem, że gospodarstwa rolnicze w krajach Unii Europejskiej maja głównie charakter rodzinny (Kowalczyk i Sobiecki, 2011), zauważono potrzebę zbadania zależności dochodu z gospodarstwa rolnego od subsydiów otrzymywanych ze środków wspólnej polityki rolnej w przeliczeniu na jednostkę pracy rodziny (FWU). Podejście to wydaje się być uzasadnione jeśli przyjrzymy się definicji gospodarstw rodzinnych: F. Tomczak $(1998,340)$ definiuje gospodarstwo rodzinne jako samodzielną jednostką produkcyjna, gdzie podstawowe czynniki produkcji są w posiadaniu właściciela (rodziny), który pełni funkcje kierownicze. Praca wykonywana jest głównie przez właściciela i jego rodzinę, a własność i zarządzanie przekazywane są z pokolenia na pokolenie. A. Woś $(1996,53)$ dodaje, iż gospodarstwo rodzinne dąży do długookresowego celu, za który uznaje zapewnienie trwania rodziny i tworzenie warunków rozwoju przyszłych generacji. Rolnik dąży nie tylko o maksymalizacji dochodu bieżącego, ale i do gwarancji zatrudnienia wszystkim członkom rodziny. $\mathrm{W}$ związku $\mathrm{z}$ wielowymiarowością celów rodzinne gospodarstwo rolnicze zachowuje się inaczej niż przedsiębiorstwo nierolnicze, oparte o najemną siłę roboczą. W związku z tym istnieją sugestie, by oceniać gospodarstwa rolnicze przez pryzmat realizowanych celów - nie tylko ekonomicznych, ale także celów członków gospodarstwa domowego (Adamowicz, 2005, 80). 
Produkcja mleka niewątpliwie cechuje się specyfiką, z której wynikają określone konsekwencje. A. Parzonko (2013, 54-55) z punktu widzenia ekonomicznoorganizacyjnego wyróżnia kilka cech produkcji mleka na tle innych działalności rolniczych, wśród których znalazły się, te które znacząco oddziałują także na poziom uzyskiwanych dochodów, tj. wysoka pracochłonność i kapitałochłonność produkcji mleka w stosunku do innych działalności rolniczych oraz wyraźne powiązanie produkcji mleka z produkcją roślinną w gospodarstwie rolniczym. Niezbędne w chowie zwierząt przeżuwających, w tym krów mlecznych, są pasze objętościowe, które ze względu na małą dostępność na rynku, muszą być wytworzone w gospodarstwie mlecznym absorbując przy tym znaczną część zasobów ziemi. Stosunkowo duże zasoby ziemi niezbędne są także w celu właściwego zagospodarowania nawozów organicznych, powstałych $\mathrm{w}$ wyniku skoncentrowanej produkcji. Autor podkreśla, że jeśli powyższe cechy nie są rekompensowane ceną produktu lub subwencjami kierowanymi do rolników zajmujących się produkcją mleka, uniemożliwia to osiaganie odpowiednich poziomów dochodu.

Problematyka kształtowania się dochodów gospodarstw mlecznych zarówno w Polsce, jak i w Unii Europejskiej jest tematem licznych opracowań naukowych. Można tu wymienić opracowania Ziętary (2003, 2006, 2010), Swittyka i Ziętary (2008 i 2012), Wójcika (2010, 2012), Parzonko (2006, 2013), Szajnera (2010, 2014), Grontkowskiej (2012), czy Sassa (2004, 2007). W większości przypadków pomijają one jednak problem wpływu subsydiów WPR na dochody gospodarstw określonych typów produkcyjnych. Również opracowania zagraniczne poruszają ten problem tylko w ograniczonym zakresie (Bouamra-Mechemache, Jongeneel i Requillart, 2000, 2007; Lehtonen, 2008). Szeroko w literaturze jest natomiast opisana ewolucja mechanizmów wspólnej polityki rolnej dotyczącej rynku mleka wraz z konsekwencjami wprowadzonych zmian (por. Szajner (2014), jak również wskazywane są kierunki jej dalszego rozwoju (por. Guba i Dąbrowski (2012) i Parzonko (2008)). O ile statystyki dotyczące wielkości dochodów, udziału wsparcia publicznego w krajach Unii Europejskiej i wysokości poszczególnych subsydiów w poszczególnych krajach są ogólnie dostępne, o tyle ich kompletna interpretacja wymaga dopracowania. Wyniki badań pomogą odpowiedzieć na pytanie, jaki był wpływ subsydiów WPR na dochody $\mathrm{z}$ gospodarstwa rolnego/FWU oraz które grupy subsydiów i w jakim stopniu wpływały na dochody z gospodarstwa rolnego/FWU w gospodarstwach mlecznych FADN w krajach Unii Europejskiej w latach 2005-2013.

\section{Dane i metody}

Badania przeprowadzono przy użyciu danych EU FADN dla typu produkcyjnego (TF8) krowy mleczne w okresie 2004-2013. W celu zapewnienia porównywalności danych oraz określenia dochodów producentów mleka w krajach Unii Europejskiej dane przeliczono na jednostkę pracy własnej (FWU). Celem oceny wpływu dopłat unijnych na dochód gospodarstw mlecznych przedstawiono ich udział $w$ dochodzie netto $\mathrm{z}$ gospodarstwa rolnego w przeliczeniu na FWU oraz zaprezentowano kształtowanie sie poziomu dochodu bez i zwyłączeniem dopłat w badanym okresie dla całej Unii 
Europejskiej oraz $\mathrm{w}$ grupach UE-15 i UE-1033. Następnie zbadano wpływ różnych grup subsydiów na dochód netto z gospodarstwa rolnego w przeliczeniu na jednostkę pracy rodziny (FWU). Ponieważ analizowane dane są połączonymi danymi przekrojowymi (dla krajów UE) i danymi dotyczącymi szeregów czasowych $\left(2005^{4}\right.$-2013) przeprowadzono regresję panelowa. Po analizie wykresu rozrzutu, zdecydowano o zastosowaniu modelu potęgowego (którego dopasowanie okazało się zgodnie z przewidywaniami lepsze niż modelu liniowego), wobec czego zlogarytmowano obie strony równania i otrzymano funkcję zmiennej zależnej y:

$$
\begin{gathered}
\ln Y=\ln (X 1)+\ln (X 2)+\ln (X 3)+\ln (X 4)+\ln (X 5) \\
\ln Y i t=\alpha \ln X 1_{i t}+\beta \ln X 2_{i t}+\delta \ln X 3_{i t}+\gamma \ln X 4_{i t}+\varepsilon \ln X 5_{i t}+b_{i t}
\end{gathered}
$$

gdzie:

$\mathrm{Y}_{i t}$ - dochód netto z gospodarstwa rolnego/ FWU w krajach UE $i$ i latach $t$ (SE430)

$\mathrm{X} 1_{\text {it }}$ - wartość dopłat do dóbr publicznych (rozumiana jako suma płatności z tytułu odłogowania i rolnośrodowiskowych, wsparcia dla obszarów o niekorzystnych warunkach gospodarowania $\mathrm{i}$ innych dopłat $\mathrm{w}$ ramach programów wsparcia obszarów wiejskich w przeliczeniu na FWU);

$\mathrm{X} 2_{\mathrm{it}}-$ wartość dopłat do produkcji roślinnej i zwierzęcej (suma innych dopłat do produkcji roślinnej i zwierzęcej, salda dopłat i kar dla producentów mleka, dopłat do pozostałego bydła oraz dopłat do owiec i kóz w przeliczeniu na FWU);

$\mathrm{X} 3_{\text {it }}$ - wartość jednolitych płatności obszarowych w przeliczeniu na FWU;

$\mathrm{X} 4_{\mathrm{it}}-$ wartość dopłat do zużycia pośredniego w przeliczeniu na FWU;

$\mathrm{X} 5_{\mathrm{it}}-$ wartość dopłat do inwestycji w przeliczeniu na FWU.

Następnie skonstruowano zwykłe modele regresji klasyczną metodą najmniejszych kwadratów (KMNK). Ze względu na konieczność odrzucenia hipotezy zastosowania tego podejścia (opartej na teście Breuscha-Pagana) oszacowano model panelowy o losowych efektach (RE). Ocena, które z modeli panelowych (FE o stałych czy RE losowych efektach) jest właściwy, została przeprowadzona na podstawie testów Hausmana. Współliniowość zmiennych oceniano na podstawie współczynników inflacji wariancji (Varians Inflation Factors - VIF), które były znacznie poniżej wartości krytycznej VIF $=10$ dla wszystkich zmiennych (nie przekraczały 4), wobec czego uznano, że można przeprowadzić wnioskowanie na podstawie powyższego modelu.

\section{Wyniki badań}

W celu oceny wpływu dopłat unijnych na dochód gospodarstw mlecznych przedstawiono ich udział $\mathrm{w}$ dochodzie netto $\mathrm{z}$ gospodarstwa rolnego $\mathrm{w}$ przeliczeniu na FWU w krajach Unii Europejskiej razem oraz w grupach krajów UE-10 i UE-15 (por. rys.

\footnotetext{
3 Celem zachowania porównywalności poszczególnych analizowanych okresów zrezygnowano z ujęcia w zestawieniu Bułgarii, Rumunii i Chorwacji, które zostały objęte mechanizmami WPR później i znacząco wpływałyby na uzyskane wyniki.

${ }^{4}$ Ze względu na niepełny rok uczestnictwa w mechanizmach WPR aż 10 krajów członkowskich wartości z roku 2004 nie były porównywalne.
} 
1). W całym badanym okresie średni udział dopłat w dochodzie z gospodarstwa rolnego na FWU znacznie przekraczał $100 \%$, co może być podstawą do stwierdzenia, że gospodarstwa mleczne wymagają wsparcia. W trakcie procedury badawczej zastanawiano się jaki wpływ wywiera na to zjawisko skala produkcji, jednakże braki danych w EU FADN dla klas wielkości ekonomicznej ES6 w grupie gospodarstw mlecznych (TF8 krowy mleczne) uniemożliwiły wnioskowanie. Zdecydowano zatem o podziale gospodarstw mlecznych na te z krajów UE-15 i UE-10, uznając, że wciąż utrzymują się pomiędzy nimi różnice we wskaźnikach produkcyjno-ekonomicznych, na co wcześniej wskazywały wcześniej przeprowadzone badania w skali regionalnej (Guth, 2015). Różnice w udziałach subsydiów w tych dwóch grupach okazały się być znaczące - w całym badanym okresie udział subsydiów w dochodzie z gospodarstwa rolnego/FWU w krajach UE-15 kształtował się poniżej $100 \%$, natomiast w krajach UE-10 udział ten był znacząco wyższy i kształtował się od 331 do nawet 1260\%. Tak wysoki udział subsydiów w średnich dochodach z gospodarstwa rolnego w krajach UE-10 w 2013 roku spowodowany był dużą nominalną wartością dopłat $\mathrm{w}$ przeliczeniu na FWU dla gospodarstw słowackich (622109,09 EUR), których dochód pomimo dopłat jako jedyny w prezentowanym zestawieniu okazał się ujemny (-25232,06 EUR). Wartość dopłat/FWU znacząco przewyższała też osiagany dochód z gospodarstwa mlecznego na Węgrzech, w Czechach i Estonii (ponad 4-krotnie). Warto zauważyć, że Komisja Europejska prezentuje zbiorcze zestawienia dotyczące udziału subsydiów w dochodach gospodarstw rolnych bez podziału na typy produkcyjne i średnio w latach 2011-2015 dla krajów UE-15 wartość subsydiów ogółem łącznie z płatnościami bezpośrednimi wynosiła ok 65\%, dla krajów UE-13 wskaźnik ten kształtował się na poziomie $127 \%$ (Share..., 2017).

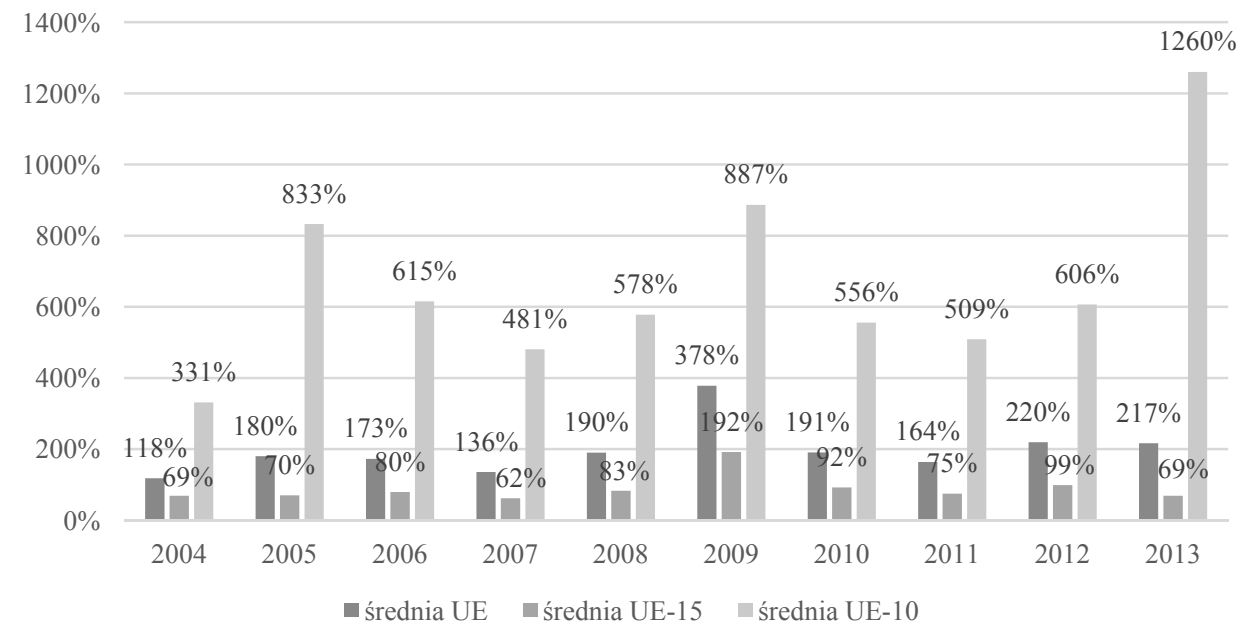

Rys. 1. Udział subsydiów ogółem łącznie z subsydiami do inwestycji w przeliczeniu na FWU w dochodzie z gospodarstwa rolnego/ FWU w gospodarstwach mlecznych FADN w latach 2004-2013

Fig. 1. Share of total subsidies including subsidies on investments per FWU in family farm income in FADN dairy farms for 2004-2013

Źródło: opracowanie własne na podstawie danych EU FADN. 


\section{M. Guth, K. Smędzik-Ambroży}

Ze względu na stwierdzenie tak dużego udziału subsydiów $\mathrm{w}$ dochodzie $\mathrm{z}$ gospodarstwa rolnego/FWU zdecydowano o przedstawieniu statystyk nominalnych (por. tab. 1), z których wynika, że w krajach Unii Europejskiej zbiorczo w całym badanym okresie dochód $\mathrm{z}$ wyłączeniem dopłat był ujemny. Tylko w grupie gospodarstw mlecznych z krajów UE-10 notowano dodatni dochód z gospodarstwa rolnego/FWU z wyjątkiem roku 2009, który był rokiem kryzysowym na rynku żywnościowym.

Tabela 1. Średni roczny dochód z gospodarstwa rolnego na FWU z dopłatami i bez dopłat z wspólnej polityki rolnej w UE-25, UE-15 i UE-10 w latach 2004-2013 w euro.

Table 1. Average annual family farm income (per FWU) with and without subsidies from the Common Agricultural Policy in the EU-25, EU-15 and EU-10 for the period 2004-2013 in euro.

\begin{tabular}{|c|c|c|c|c|c|c|}
\hline Wyszczególnienie & $\begin{array}{l}\text { Średni dochód } \\
\text { z gosp. } \\
\text { rolnego/FWU }\end{array}$ & $\begin{array}{c}\text { Średni dochód } \\
\text { z gosp. } \\
\text { rolnego bez } \\
\text { dopłat/FWU }\end{array}$ & $\begin{array}{l}\text { Średni dochód } \\
\text { z gosp. } \\
\text { rolnego w } \\
\text { UE15/FWU }\end{array}$ & $\begin{array}{l}\text { Średni dochód } \\
\text { z gosp. } \\
\text { rolnego w } \\
\text { UE15 bez } \\
\text { dopłat/FWU }\end{array}$ & $\begin{array}{l}\text { Średni dochód } \\
\text { z gosp. } \\
\text { rolnego w } \\
\text { UE10/FWU }\end{array}$ & $\begin{array}{l}\text { Średni dochód } \\
\text { z gosp. } \\
\text { rolnego w } \\
\text { UE10 bez } \\
\text { dopłat/FWU }\end{array}$ \\
\hline 2004 & 15463,97 & $-2812,64$ & 20632,11 & 6413,98 & 7424,63 & $-6899,44$ \\
\hline 2005 & 17474,46 & $-14055,13$ & 24555,68 & 7328,07 & 6459,22 & $-47317,90$ \\
\hline 2006 & 18222,10 & $-13215,48$ & 24740,95 & 5059,46 & 8081,65 & $-41643,16$ \\
\hline 2007 & 24553,08 & $-8752,67$ & 33258,56 & 12560,00 & 11011,21 & $-41905,72$ \\
\hline 2008 & 20024,22 & $-18012,01$ & 25801,80 & 4329,39 & 11036,87 & $-52765,29$ \\
\hline 2009 & 10538,12 & $-29296,45$ & 12674,75 & $-11637,23$ & 7214,48 & $-56766,34$ \\
\hline 2010 & 20555,26 & $-18665,23$ & 26598,19 & 2007,24 & 11155,15 & $-50822,39$ \\
\hline 2011 & 25147,83 & $-16128,34$ & 32815,79 & 8222,26 & 13219,90 & $-54007,05$ \\
\hline 2012 & 19889,29 & $-23774,27$ & 24905,15 & 297,48 & 12086,84 & $-61219,22$ \\
\hline 2013 & 23559,16 & $-27517,50$ & 33903,61 & 10485,91 & 7467,78 & $-86633,91$ \\
\hline
\end{tabular}

Źródło: opracowanie własne na podstawie danych EU FADN.

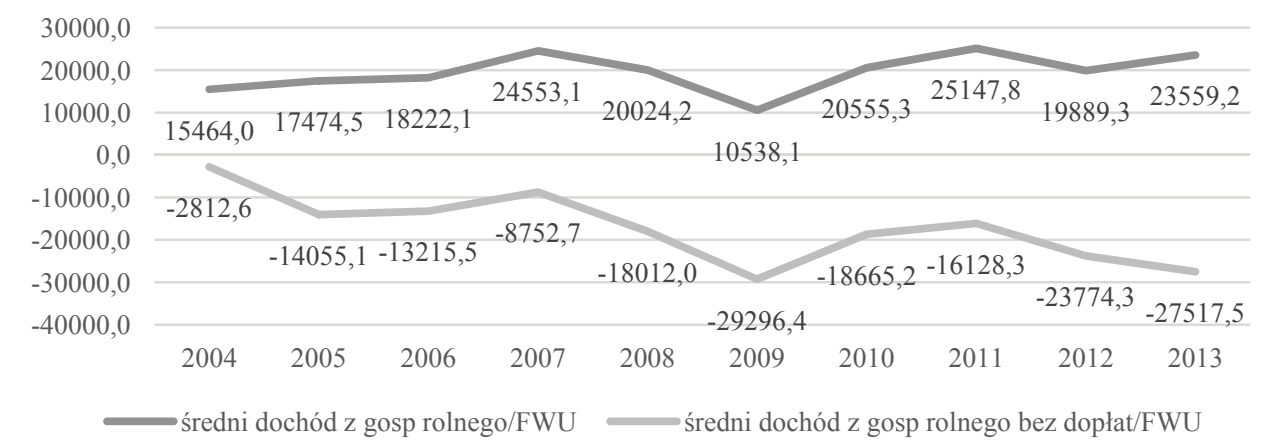

Rys. 2. Średni dochód z gospodarstwa rolnego/ FWU z dopłatami i bez dopłat ze wspólnej polityki rolnej w gospodarstwach mlecznych FADN w krajach UE w latach 2004-2013 w euro

Fig. 2. Average farm income / FWU with and without subsidies from the Common Agricultural Policy on dairy farms FADN in EU countries in 2004-2013 in euro

Źródło: opracowanie własne na podstawie danych EU FADN. 
W związku z powyższym postanowiono przedstawić tendencje kształtowania się dochodu z gospodarstwa rolnego/FWU z i bez wyłączenia subsydiów zarówno w średnio Unii Europejskiej (por. rys. 2), jak i w grupach gospodarstw mlecznych z krajów UE-15 (por. rys. 3) i UE-10 (por. rys. 4). Należy zauważyć, że dla UE-25 średni dochód wraz z dopłatami wykazywał niewielką tendencję wzrostową podczas gdy dochód z gospodarstwa rolnego/FWU po odjęciu sumy subsydiów wraz z subsydiami do inwestycji cechował się tendencją spadkową.

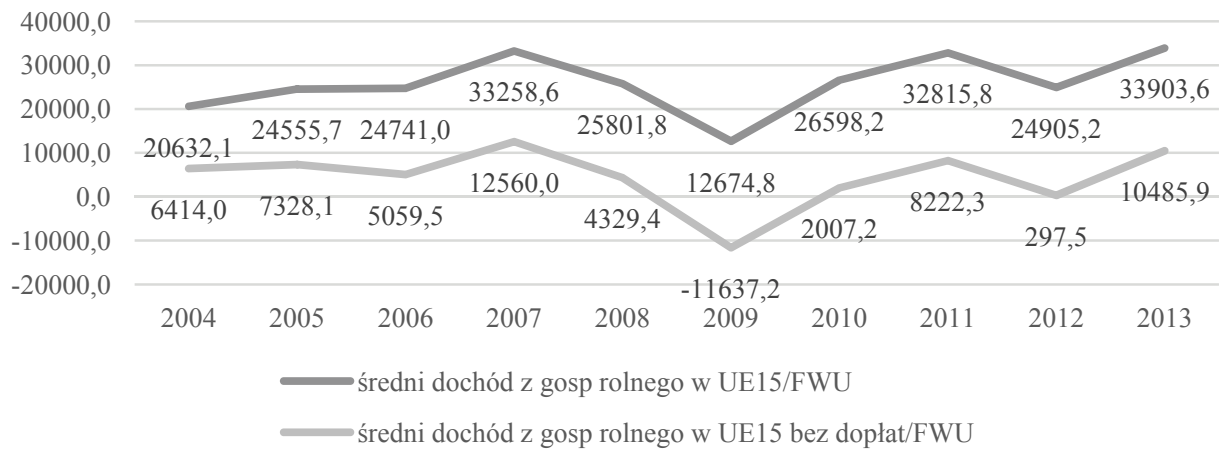

Rys. 3. Średni dochód z gospodarstwa rolnego/ FWU z dopłatami i bez dopłat ze wspólnej polityki rolnej w gospodarstwach mlecznych FADN w krajach UE-15 w latach 2004-2013 w euro

Fig. 3. Average farm income / FWU with and without subsidies from the Common Agricultural Policy on dairy farms FADN in EU-15 countries in 2004-2013 in euro

Źródło: opracowanie własne na podstawie danych EU FADN.

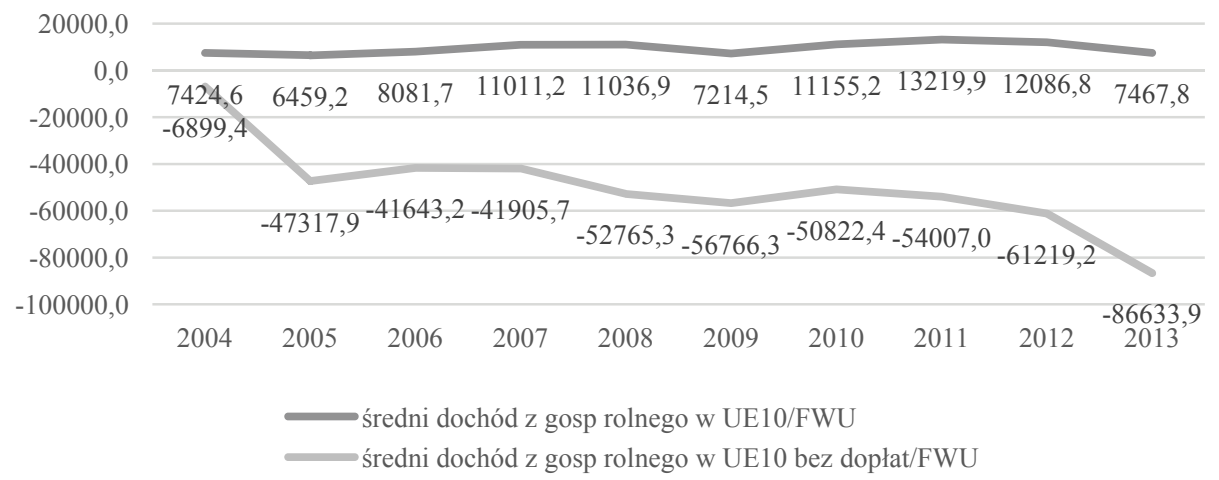

Rys. 4. Średni dochód z gospodarstwa rolnego/ FWU z dopłatami i bez dopłat z wspólnej polityki rolnej w gospodarstwach mlecznych FADN w krajach UE-10 w latach 2004-2013 w euro

Fig. 4. Average farm income / FWU with and without subsidies from the Common Agricultural Policy on dairy farms FADN in EU-10 countries in 2004-2013 in euro

Źródło: opracowanie własne na podstawie danych EU FADN. 
Dochód z i bez dopłat w krajach UE-15 kształtował się bardzo podobnie, na co wskazuje również stabilny udział dopłat $\mathrm{w}$ tej grupie zaobserwowany na rysunku 1 . W grupie krajów UE-10 dochód z uwzględnieniem dopłat był względnie stabilny, jednakże przedstawienie statystyk dochodu $\mathrm{z}$ gospodarstwa rolnego bez uwzględnienia subsydiów nasuwa negatywne wnioski. Nie tylko w całym badanym okresie dochód z gospodarstwa rolnego/FWU w krajach UE-10 był ujemny, ale wykazywał tendencję spadkową. O ile początkowe ujemne saldo można by tłumaczyć koniecznością modernizacji gospodarstw i zaciagnnięciem długoterminowych zobowiązań na ten cel, o tyle spadkowa tendencja wskazywałaby jednak na nieefektywność poczynionych inwestycji (por. rys. 4).

W drugim etapie badania celem było oszacowanie, które programy WPR mają wpływ na dochody $\mathrm{z}$ gospodarstwa rolnego $\mathrm{w}$ przeliczeniu na FWU w klasach wielkości ekonomicznej. Przeprowadzono analize regresji panelowej. W związku $\mathrm{z}$ wymogiem stworzenia takiego samego przekroju danych dla wszystkich badanych lat do analizy włączono 23 kraje członkowskie Unii Europejskiej bez Bułgarii, Rumunii, Chorwacji, które nie funkcjonowały w warunkach WPR przez cały badany okres oraz Grecji i Cypru, gdzie zasada tajności zgodnie $\mathrm{z}$ metodologią EU FADN nie pozwoliła na uzyskanie ciagłości szeregu czasowego gospodarstw o typie produkcyjnym TF8 krowy mleczne. Na podstawie testu Hausmana stwierdzono, że model z efektami losowymi okazał się być odpowiedni, co oznacza, że nie występują istotne statystycznie różnice pomiędzy wpływem poszczególnych grup subsydiów na dochody $\mathrm{z}$ gospodarstwa rolnego na FWU w poszczególnych krajach Unii Europejskiej. Należy przypomnieć, że analizujemy stos danych przekrojowych (lata 2005-2013 dla wszystkich badanych krajów), a zatem "within $\mathrm{R}^{2 \prime \prime}$ przypisuje zmienność dochodów $\mathrm{z}$ gospodarstwa rolnego w przeliczeniu na FWU do zmiennych objaśniających, które zmieniają się także w czasie. Ich zmienność w czasie jednakże w modelu okazała się być nieistotna statystycznie.

Tabela 2. Wpływ poszczególnych grup subsydiów na dochód z gospodarstwa rolnego netto w przeliczeniu na FWU w latach 2005-2013 świetle regresji panelowej (RE model)

Table 2. Influence of individual subsidy groups on net farm income in the years 2005-2013 in the light of panel regression (RE model)

\begin{tabular}{|c|c|c|c|c|c|}
\hline Wyszczególnienie & Współczynnik & Błąd stand. & $\mathrm{z}$ & Wartość p & \\
\hline stała & 8,91227 & 0,6059050 & 14,7090 & $<0,0001$ & *** \\
\hline dopłaty do dóbr publicznych/FWU & $-0,123024$ & 0,0928672 & $-1,3247$ & 0,1853 & \\
\hline dopłaty do produkcji/FWU & 0,0128153 & 0,0288171 & 0,4447 & 0,6565 & \\
\hline Płatności decoupled/FWU & 0,13508 & 0,0522416 & 2,5857 & 0,0097 & $* * *$ \\
\hline dopłaty do zużycia pośredniego/FWU & 0,00758334 & 0,0263632 & 0,2876 & 0,7736 & \\
\hline dodatkowe wsparcie i pozostałe dopłaty/FWU & 0,0515543 & 0,0210759 & 2,4461 & 0,0144 & $* *$ \\
\hline
\end{tabular}

\begin{tabular}{lr|lr}
\hline \multicolumn{2}{c}{} \\
\hline Średn. aryt. zm. zależnej & 9,456770 & Odch. stand. zm. zależnej & 0,642154 \\
Suma kwadratów reszt & 37,69750 & Błąd standardowy reszt & 0,607934 \\
Logarytm wiarygodności & $-96,01335$ & Kryt. inform. Akaike'a & 204,0267 \\
Kryt. bayes. Schwarza & 220,0637 & Kryt. Hannana-Quinna & 210,5279 \\
\hline
\end{tabular}

'Between' wariancji $=0,327566$ Within' wariancji $=0,0577717$ mean theta $=0,820878$

Test Breuscha-Pagana na - Hipoteza zerowa: Wariancja błędu w jednostce $=0$

Asymptotyczna statystyka testu: Chi-kwadrat $(1)=131,846 \mathrm{z}$ wartością $\mathrm{p}=1,61682 \mathrm{e}-030$

Test Hausmana - Hipoteza zerowa: Estymator UMNK (GLS) jest zgodny

Asymptotyczna statystyka testu: Chi-kwadrat $(5)=7,72041 \mathrm{z}$ wartością $\mathrm{p}=0,172332$

Źródło: opracowanie własne na podstawie danych FADN. 
Tylko dwie spośród zmiennych w modelu są statystycznie istotne (wartości p nie przekraczają 0,1 ) i są to płatności decoupled oraz dodatkowe wsparcie i pozostałe dopłaty. Do granicy istotności zbliża się także grupa dopłat do dóbr publicznych. Można zatem wnioskować, że to właśnie te dopłaty miały znaczący statystycznie wpływ na zmienność dochodu z gospodarstwa rolnego/FWU w krajach Unii Europejskiej w latach 2005-2013. Do podobnych wniosków doszli także Gołasa (2010) ukazując wpływ dopłat bezpośrednich i ONW na dochód z gospodarstwa rolnego w Polsce oraz Marks-Bielska i Babuchowska (2009). Zaskakującym zjawiskiem zdał się być brak istotności parametru dotyczącego dopłat do produkcji, jednakże po analizie jego składowych oraz szeregu danych zauważono, że w związku $\mathrm{z}$ wzięciem pod uwagę salda kar, udział tej zmiennej w dochodach z gospodarstwa rolnego/FWU nie był aż tak znaczący, co więcej zdarzało się (częściej pod koniec okresu badawczego, kiedy część producentów decydowała się zwiększać skalę produkcji ze względu na likwidację kwot mlecznych nie patrząc na konsekwencje w postaci kar), że wartość tych świadczeń była ujemna.

\section{Podsumowanie}

Podsumowując przedstawione wyżej rozważania należy jednoznacznie stwierdzić, że subsydia wspólnej polityki rolnej znacząco wpływały na poziom dochodów z gospodarstwa rolnego/FWU w gospodarstwach mlecznych FADN w latach 2004-2013. W gospodarstwach z krajów UE-10 pozwalały na uzyskiwanie dodatnich dochodów. Średni udział wartości dopłat ogółem wraz z dopłatami do inwestycji w dochodzie z gospodarstwa rolnego w przeliczeniu na jednostkę pracy własnej w gospodarstwach mlecznych FADN w latach 2004-2013 wahał się od 119 do $220 \%$ w krajach UE-25. Udziały te w krajach UE-15 i UE-10 kształtowały się w przedziałach odpowiednio: 62-99\% i 331-1260\%, co znacząco przewyższało średnią dla gospodarstw wszystkich typów produkcyjnych. Negatywnie należy ocenić tendencję spadkową dochodów z gospodarstwa mlecznego bez dopłat i ich silne uzależnienie od mechanizmów instytucjonalnych, które mogą ulec zmianie w kolejnej perspektywie finansowej, zwłaszcza w obliczu likwidacji kwot mlecznych w 2015 roku. Wyniki analizy panelowej pozwoliły określić, że największe znaczenie dla dochodów z gospodarstwa mlecznego miały jednolite płatności obszarowe i jednolite płatności na gospodarstwo, dodatkowe wsparcie i pozostałe dopłaty oraz dopłaty do dóbr publicznych.

\section{Spis literatury}

Adamowicz, M. (2005). Zrównoważony i wielofunkcyjny rozwój rolnictwa a agronomia, Annales Universitatis Mariae Curie-Skłodowska Lublin - Polonia, Lublin.

Bouamra-Mechemache, Z., Requillart, V. (2000). Analysis of EU dairy policy reform, European Review of Agricultural Economics, Vol 27 (4), 409-430.

Bouamra-Mechemache, Z., Jongeneel, R., Requillart, V. (2007). The dairy industry in an expending EU policies and strategies, EDIM/KOM: Meeting at DG Agri, April 24, 2007 Brussels.

Czyżewski, A., Guth, M. (2016). Zróżnicowanie produkcji mleka w makroregionach Unii Europejskiej z wyróżnieniem Polski, PWN, Warszawa.

Dz. Urz. UE 2006 C 321E., Ośrodek Informacji i Dokumentacji Europejskiej, Wersja skonsolidowana Traktatu ustanawiającego Wspólnotę Europejską Pobrano 24 lipca $2014 \quad$ r. $\quad$ z: http://oide.sejm.gov.pl/oide/index.php?option=com_content\&view=article\&id=14436\&Itemid=436. 
Gołasa, P. (2010). Wpływ wybranych instrumentów Wspólnej Polityki Rolnej na kształtowanie się dochodów gospodarstw rolnych w Polsce. Zeszyty Naukowe Polityki Europejskiej Finanse $i$ Marketing $\mathrm{Nr} 4$ (53), 173180

Grontkowska, A. (2012). Zmiany w wynikach produkcyjnych i ekonomicznych gospodarstw mlecznych najsilniejszych ekonomicznie w latach 2004-2009 w krajach Unii Europejskiej. Roczniki Nauk Rolniczych, Seria G, T. 99, z. 1, 58-69.

Guba, W., Dąbrowski, J. (2012). Deregulacja rynku mleka w Unii Europejskiej - skutki i zalecenia dla Polski. Rocznik Nauk Rolniczych, seria G, T. 99, z. 1., 32-42.

Guth, M. (2015). Diversity of FADN milk farms in milk farms in the regions of the European Union in 2011. Roczniki Naukowe SERiA, XVII (3), 119-124.

Hergrenes, A., Hill, B., Linem, G. (2001). Income instability among farm households - evidence from Norway. Farm Management. Journal of the Institute of Agricultural Management, 11(1), 37-48.

Kowalczyk, S., Sobiecki, R. (2011). Europejski model rolnictwa wobec wyzwań, Zagadnienia Ekonomiki Rolnej, Wydawnictwo IERiGŻ-PIB, z. 4.

Lehtonen, H. (2008). Impact of phasing out milk quotas on structure and production of Finnish dairy sector, MTT Agrifood Research Finland, Economic Research, Helsinki 2008.

Majewski, E., Wąs, A., Guba, W., Dalton, G. (2007). Oszacowanie ryzyka dochodów rolniczych w gospodarstwach mlecznych w Polsce na tle gospodarstw innych kierunków produkcji w warunkach różnych scenariuszy polityki rolnej. Rocz. Nauk Roln., seria G, t. 93, z. 2, 98-106.

Marks-Bielska, R., Babuchowska K. (2009). Wsparcie dochodów rolników w formie dopłat bezpośrednich. Zeszyty Naukowe Szkoły Gtównej Gospodarstwa Wiejskiego w Warszawie Ekonomika i Organizacja Gospodarki Żywnościowej nr 75, 135-148.

Phimister, E., Roberts, D., Gilbert, A. (2004). The Dynamics of Farm Incomes. Journal of Agricultural Economics, t. 55, 2, 197-220.

Runowski, H. (2011). Zmienność dochodów gospodarstw rolnych w krajach Unii Europejskiej i jej przyczyny, Roczniki Naukowe SERiA, tom XIII, zeszyt 1, 327-331.

Parzonko, A. (2006). Możliwości rozwojowe gospodarstw ukierunkowanych na produkcję mleka. Roczniki Nauk Rolniczych, Seria G Ekonomika Rolnictwa, t. 93, z. 1, 83-91.

Parzonko, A. (2008). Strategie rozwoju polskich gospodarstw ukierunkowanych na produkcję mleka w kontekście Wspólnej Polityki Rolnej UE, Wydawnictwo SGGW, Warszawa. G, t. 97, z. 4, 157 - 170.

Parzonko, A. (2013). Globalne i lokalne uwarunkowania rozwoju produkcji mleka, Wydawnictwo Szkoły Głównej Gospodarstwa Wiejskiego w Warszawie, Warszawa.

Sass, R. (2004). Sytuacja ekonomiczna gospodarstw specjalizujących się w produkcji mleka. Roczniki Naukowe SERiA, Tom IV, z.1, Warszawa- Poznań-Puławy, 189-194.

Sass, R. (2007). Wielkość stada a dochód z zarządzania w gospodarstwach wyspecjalizowanych w chowie bydła mlecznego, Roczniki Nauk Rolniczych, Seria G, T. 93, z. 2, 71-79.

Share of direct payments and total subsidies in agricultural factor income (2011-15 average). Pobrano 10 marca 2017 r. z: http://ec.europa.eu/agriculture/sites/agriculture/files/cap-post-2013/graphs/graph5 en.pdf.

Szajner, P. (2010). Sektor mleczarski w Polsce - problemy i perspektywy. Przemyst Spożywczy, nr 7-8, 28 - 34.

Szajner, P. (2014). Wpływ likwidacji kwot mlecznych i zmian regulacji rynku mleka na perspektywy rozwoju polskiego mleczarstwa. Pobrano 20 czerwca 2015 r. z: https://www.ierigz.waw.pl/download/NDYyMg==.

Świtłyk, M., Ziętara, W. (red.) (2008). Analiza efektywności produkcji mleka i żywca wołowego - Raport 2008, Wyd. Akademii Rolniczej w Szczecinie, Szczecin.

Świtłyk, M., Ziętara, W. (red.) (2012). Analiza efektywności produkcji mleka i żywca wołowego. Raport 2012, Wydawnictwo SGGW, Warszawa.

Tomczak, F. (1998). Hasło „gospodarstwo rodzinne”, w: Encyklopedia agrobiznesu, Wydawnictwo Fundacja Innowacja, Warszawa.

Woś, A. (1996). Agrobiznes - mikroekonomia, t. 2, Wydawnictwo Key Text, Warszawa.

Wójcik, A. (2010). Koszty i dochodowość produkcji mleka w gospodarstwach krajów europejskich. Roczniki Nauk Rolniczych, Seria G, t. 97, z. 1, 67-73.

Wójcik, A. (2012). Koszty i dochodowość produkcji mleka w europejskich gospodarstwach utrzymujących do 50 krów. Roczniki Nauk Rolniczych, Seria G, t. 99, z.1, 100-107.

Ziętara, W. (2003). Efektywność produkcji mleka w wybranych gospodarstwach mlecznych w Polsce i w Unii Europejskiej. Przeglad Hodowlany nr 2, 4-8.

Ziętara, W. (2006). Ekonomiczne i organizacyjne aspekty produkcji mleka przy wysokiej wydajności krów. Przeglad Hodowlany nr 12, 1-4.

Ziętara, W. (2010). Koszty i dochodowość produkcji mleka w polskich gospodarstwach w latach 2006-2008. Roczniki Nauk Rolniczych, Seria G Ekonomika Rolnictwa T. 97, z. 1, 53-66. 